
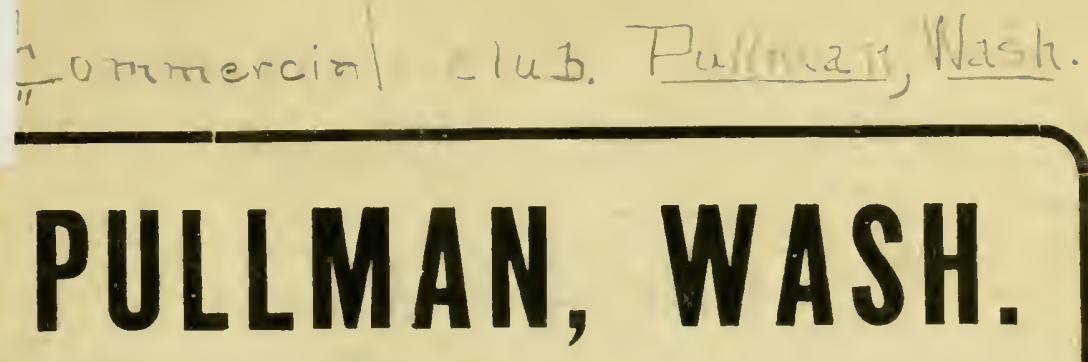

AND THE

FAMOUS PALOUSE COUNTRY.

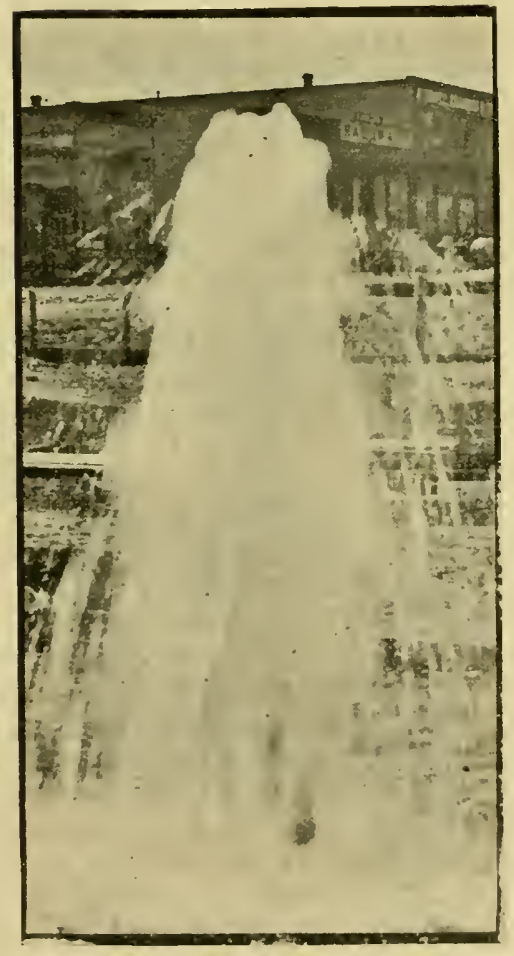

One of Pullman's Fourteen Artesian Wells * * * *
The Palouse Country

where

Grains,

Fruits and

Vegetables

Grow to the

Greatest Perfection

Without Irrigation.

$$
\text { t }
$$

Pullman ...

the

Commercial

Center of

the

Palouse

Country.

"City of Schools."

"City of Elowing Wells." 


\section{To the Homeseeker:}

This panphlet is intended for the intelligent progressive lomeseeker, who, more or less dissatisfied, desires his new home to be surrounded by a bounteous nature and yet not be deprived or have his family deprived of the advantages of an advanced civilization. Such is the section to which we invite the homeseeker's attention.

Joseph F. Wing, a practical agriculturist, stock-man and writer, well known throughout the agricultural world, recently wrote, after an extensive trip throughout the United States, "In all the long journey I have made, I have never seen anything that seems to me to have the natural advantages for human life and occupation that the Palouse country has. It seems to me that there is the best place to build a stock farm that I have seen on this trip. I never saw land too good for good stock. I was mnder a cloud while here, sick, tired and worried, yet it could not dim my enthusiasm for the glorious land. Happy is the man born in these fertile hills, if he is alive to his glorious opportunities."

Prof. Mark W. Harrington, for many years at the head of the Weather Bureau of the Agricultural Department, at Washington, D. C., recently wrote, "While there we estimated what population the Palouse country was able to maintain. Our conclusion was that one hundred times as many people could be supported by its soil as now live there. The area is a little less than that of Massachusetts and the population might be greater than that of Massachusetts and all be supported by the soil. There are no trees or rocks to be removed. Put in the plow and then plant the seed."

The opportunity here for successful diversified farming is not surpassed by any section in the United States; we make no exceptions. If the reader is a farmer, he can surround limself liere, at a small cost, with fields of great productiveness. If he is a dissatisfied business man, let him examine our "want" column. There are opportunities here promising sure success. It has been thoroughly demonstrated that stock raising, dairying, poultry raising, fruit culture and diversified farming can be conducted liere by men of ordinary intelligence and energy with no excuse for failure. Study the map at the back of this pamphlet, note our slipping facilities, and low we are surromnded by great mining centers, affording right at home a steady and ever increasing market. We ask your careful perusal of this pamphlet. For any other information you may desire, feel at liberty to write freely to

THF: PUI,IMAN COMMERCIAL, CLUB. ○

W. H. HARV'W', President.

E. S. Brogan, Secretary.

('llhe views in this pamphlet ate from photos by Bums, Inllman, Wash.)

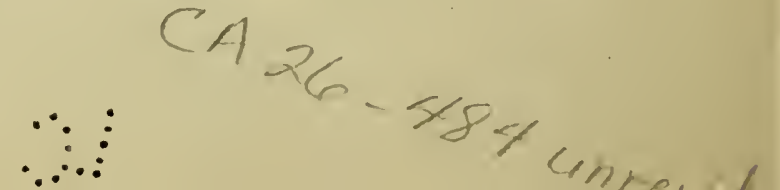




\section{AGRICULTURE}

\section{X THE VICINTY OF \\ PULLMAN, WASHINGTON.}

\section{The State as a Whole.}

IN ORDFR to convey a compreliensive idea of agriculture in the state it may be stated that Washington is divided into three very distinct Three Dis- agricultural sections. That portion lying west of the Cascade mountains is characterized by a rainfall of 40 to tinct Sections 6o inclies, and is corered by timber, nostiy evergreens. About 300,000 acres of the land is in cultivation, devoter mostly to fruit, dairying and vegetable gardening. Oats is the only inportant grain crop, and tinothy and red clover are the principal liay crop. There

The

West Side are liomes in Western Washington for thousands of men who are willing to clear the lant. The expense of clearing varies from about $\$ 30$ per acre where the timber is lightest to \$5O where the timber is heary.

The other two sections lie east of the Cascales. The one consists of valley lands adjacent the rivers in central Washington, with light, The Irrigated sandy soils, and a rainfall of 6 to ro inches, crops being Drown only uncler irrigation. There is still a consider-

District. able area of land capable of being irrigated when capitalists are willing to furnish the noney necessary to build ditches. There is also some nnoccupied land under existing ditches. The total area under irrigation $1 \mathrm{n}$ the state is about 150,000 acres. The principal crops are fruit and alfalfa.

The Palouse The renaining section consists of npland prairies where The Palouse the rainfall is sufficient to produce crops witlout irriga-

Country. tion. Wheat is the leading crop in this section, there being about 2,000,000 acres of wheat grown annually. In orler to give a clear irlea of the part of the state nuncler consicleration, it is Crops With- necessary to refer to the rainfall map acconpanying this article. It will there be seen that in the central part of out Irrigation. the state lies a large area having an average anmul rainfall of less than ro inches. The irrigated section lies within this area. 
Such parts of it as are not irrigated are covere 1 wit'i a sparse growth of bunch grass upon which sheep, horses an'l cattle are grazed. The

Rainfall. Wheat growing section lies on the outsicle of this area, principally to the east of it, the only important wheat growing areas west of the dry region being $i: 1$ western Klickitat and western Douglas county. On both sides of the dry region the rainfall increases toward the Cascade Mountains on the west, and the Mountains of Idaho on the east. The most extensive area of cultivated land

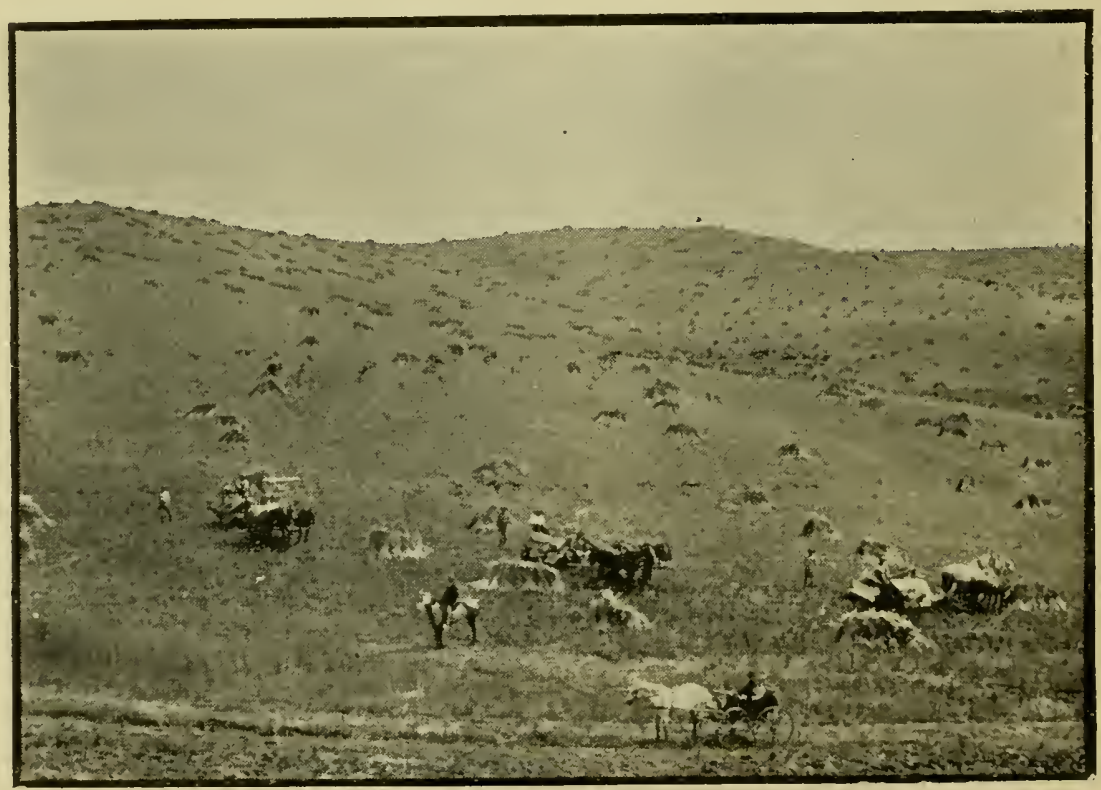

Harvest Scene near I'ullnan.

in the state lies between the Idaho line and the Io-in. rainfall line west of it. It stretches in a broad belt from the Spokane River on the north, to and across the Snake River, skirting around the base of the Blue Mountains in Southeastern Washington to Walla Walla. Between the ro and I5-incl rainfall lines the land is partly farmed and partly grazed, the rainfall being near the lower linit of the amount required for successful agriculture. Fast of the 20-inch rainfall line, crops have never been known to fail.

By consulting the rainfall map it will be seen that Pulluan is situ- 


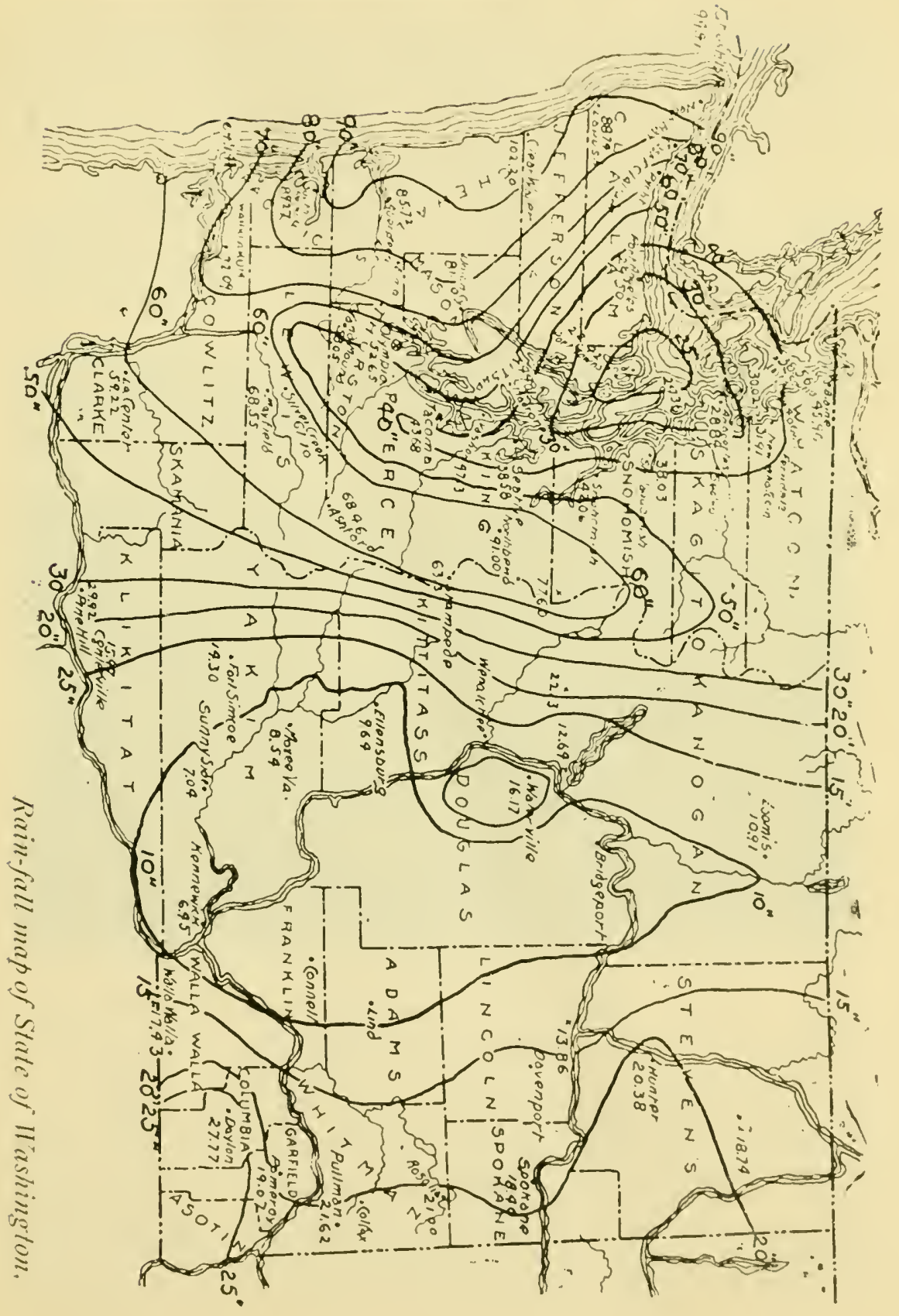


ated in the lieart of the district having a rainfall of 20 to 25 inches. (The average rainfall here for seven years past is $22.4 \mathrm{I}$ inches). It is therefore centrally located in one of the best agricultural districts of the state.

\section{Why There is Room for Immigration Here.}

This being a prairie country, and luaving soil of great fertility, it was naturally taken up early. As wheat raising proved to be the most remunerative type of farming when railroads first penetrated this

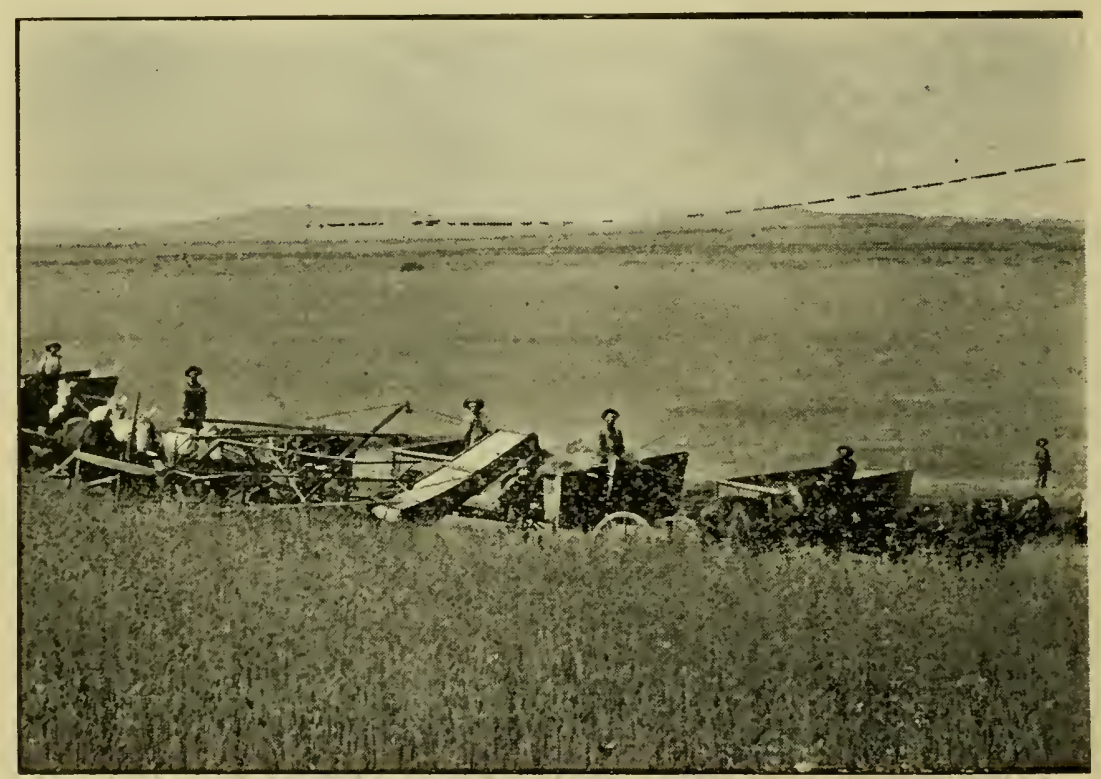

Heading Grain near Pulluan.

section, one man could farm a large area of it; the result was that settlers with considerable business acunen kept buying their neighbors" claims until the country consisted of very large farms, frequently several thousand acres belonging to one nnan. Wheat growing proveri so successful that farmers devoted themselves exclusively to the one crop, a system of farming that is frauglit with gravedangers in any country.

Farmers Now that the growtli of our cities, the development of Diversifying. mines and manufactures has made a clenund for nuore lirestock products than the country can supply, and thus 
made livestock farming more profitable than exclusive wheat growing, the farmers are beginning to learn that they can not handle Price of Farm such large areas to advantage, because they have not the annount of livestock required. The result is that Land. improved agricultural land, as good as can be found in any Eastern state, can be bought for $\$ 15$ to $\$ 25$ an acre, and occasionally for even less than this. 'This is improved land that is all in cultivation, there being practically no waste land.

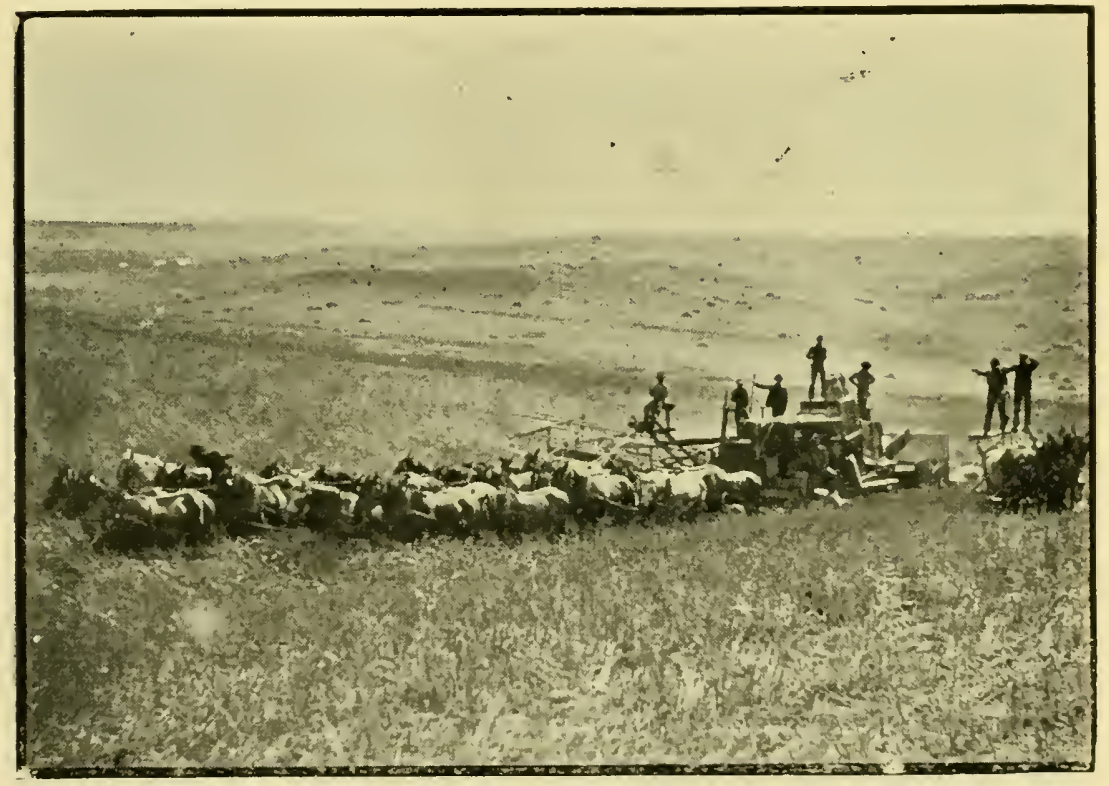

Comlined Header and Thresher in Operation near Pulluan.

\section{Character of the Soil.}

In a former geological age this whole region was covered with molten lava several thousand feet deep. The lava rocks which everywhere underlie the surface at a leptli of fifty to a lumblred feet or more, are arranged in layers, and appear at the surface only on the sides of canyons. The soil has been formed by the disintegration of the surface of this lava, and it has a texture wholly different fron any soil the writer ever saw east of the Rocky Momntains. There is ab- 
solutely no gravel in it, clear lown to the rock. It absorbs water more rapidly, and holds more of it than any other soil known except peat. Although the country is rolling, such a thing as washing of the soil is unknown except occasionally where one sees small rill marks on hillsides that have been plowed and left barein winter. The rains, which practically all fall between September and June, are never torrential in character like those of the Eastern states, and the water is absorbed by the soil as it falls. The rains penetrate the soil to a depth varying from eight to fifteen feet in the vicinity of Pullman, except in the

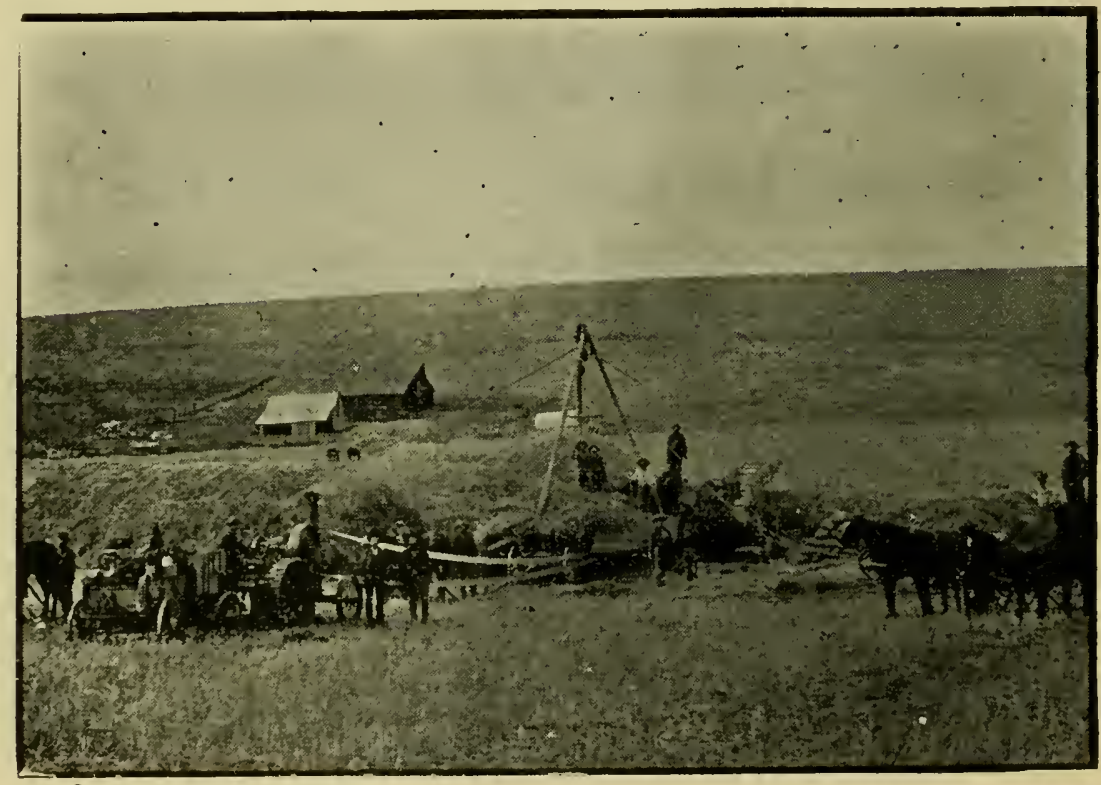

Threshing on a Palouse Farn.

draws, where it goes much deeper. It remains in this surface layer of soil till removed by plant roots the next spring and summer. Occasionally a field of grain has been sown after the spring rains were over, and a fair crop grown with no other moisture than that stored up in the soil at the time the seed was planted. There is certainly,110 extensive area of land in the world that will hold water more tenaciously, or in larger quantity, than the basaltic soils of this region. The abundant crops grown here with practically 110 rain after the first of July render this fact evident. 


\section{Climate.}

The clinate of all that region west of the Rocky Mountains is characterized by wet winters and dry summers. Where the soil is sandy, as along river bottonns, irrigation is necessary for crop growing. But on the basaltic (lava) soils of the "pland prairies of Eastern Washington, Io inches of rainfall will produce fair crops, if a fair share of it falls in April, May or June. Where the rainfall is 20 inches or more Crop Certain. on this basaltic soil, there has never been a crop failure, Crop Certain, and irrigation is unthought of. Crops here are "grown by irritation, and not by irrigation."

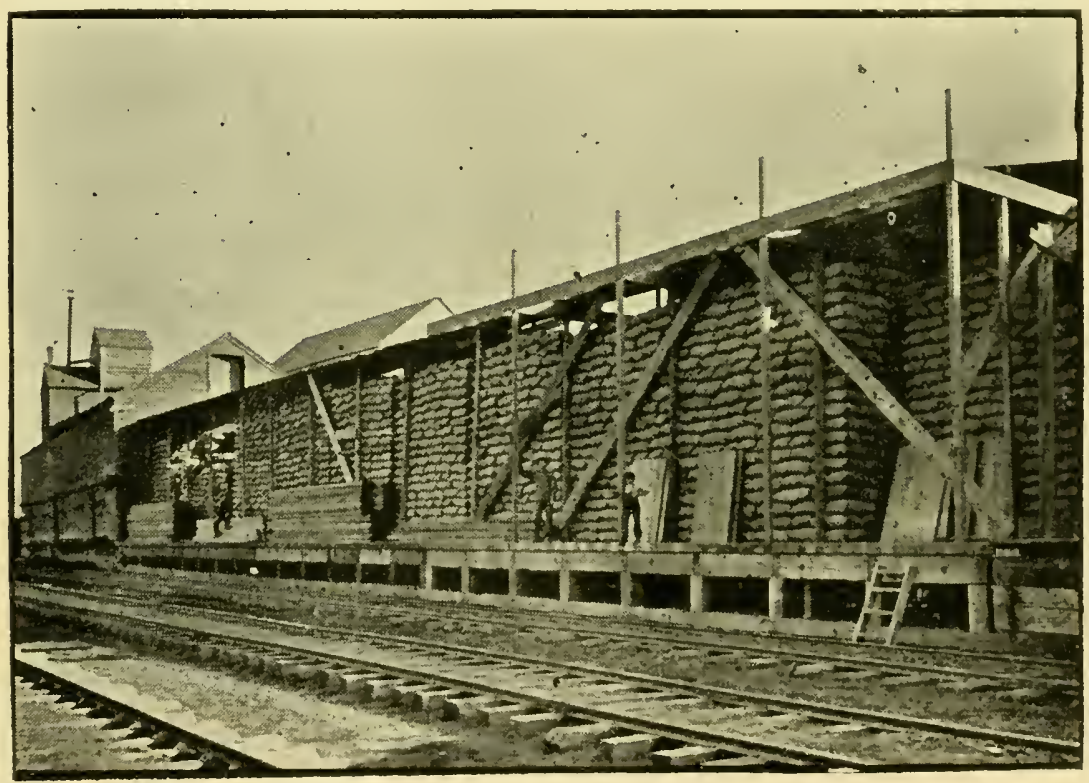

Overflow frcm Warehouse at Pullman.

We have already referred to the rainfall map, which shows the average annual rainfall for the whole state.

No

Tornadoes.

One thing which it is difficult for Eastern people to believe about this comntry is the absence of dangerous Rock y Mountains. I.ightning is so rare as to cause general comnent 
when it does occur. I have never seen a lightning rod or a lightning rod agent west of the Rockies.

The average annual temperature varies considerably in this state, owing to difference in elevation, it being abont one degree cooler for

The each 300 feet above sea level. The coldest temperature Temperature recorded here in seven years was ig degrees below zero. from two to five days long, when the temperature goes down to about zero. These cold spells always occur just after a period of snow-fall;

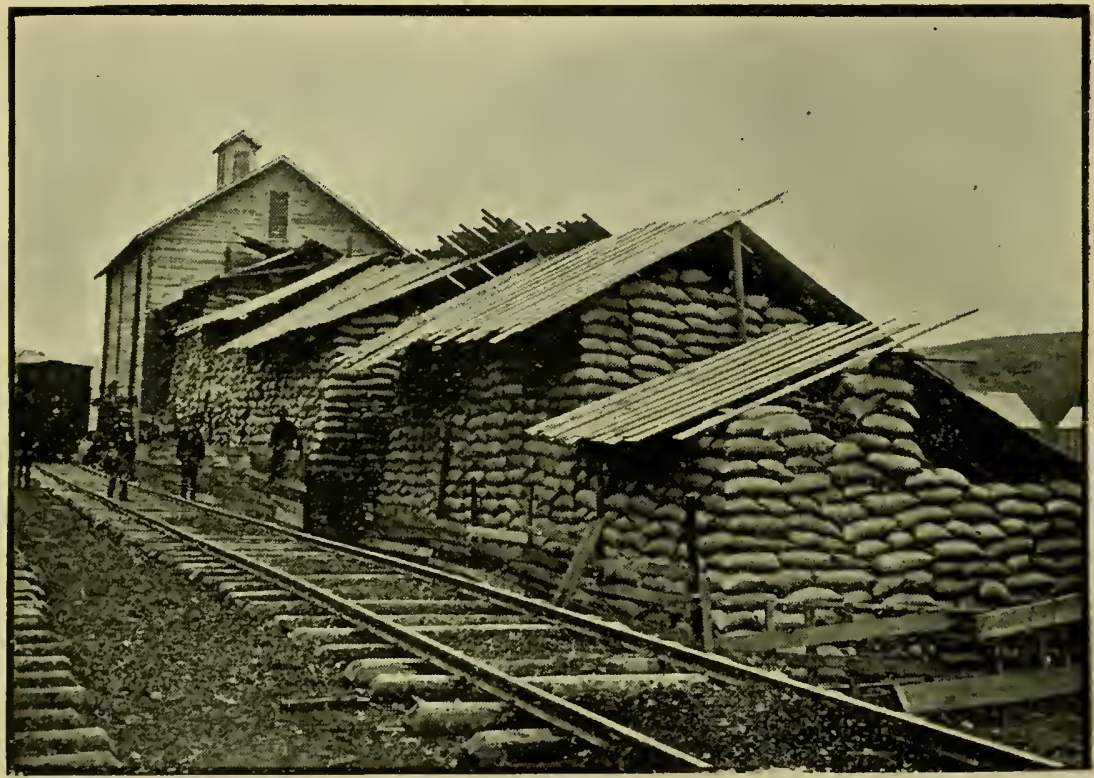

Overflow from Warehouse at Pullnan.

but the cold spell itself is always accompanied by clear skies and calm weather. The remainder of the winter season is a mixture of light rain and beatiful sunsliny weatler.

Occasionally in smmmer we have a period of a few days, and sone years for a few weeks, of rather warm weather, but the nights are invariably cool. The remainder of the summer the weather is icleal. No clinate in the world has more beantiful weather than a good portion of the early smmmer and early fall here. 
Mr. Jos. E. Wing. the well-known correspondent of the lireeder's Gazette, of Chicago, in writing his paper concerning the clinate liere, Ideal Climate. is like wine. At midlay it is only confortably warm to me. It is a land where you will ride in confort with a light top coat on in midsummer. If you happen not to have one you will get along just as well. At night you creep between two blankets, and your troubles find you not until norning."

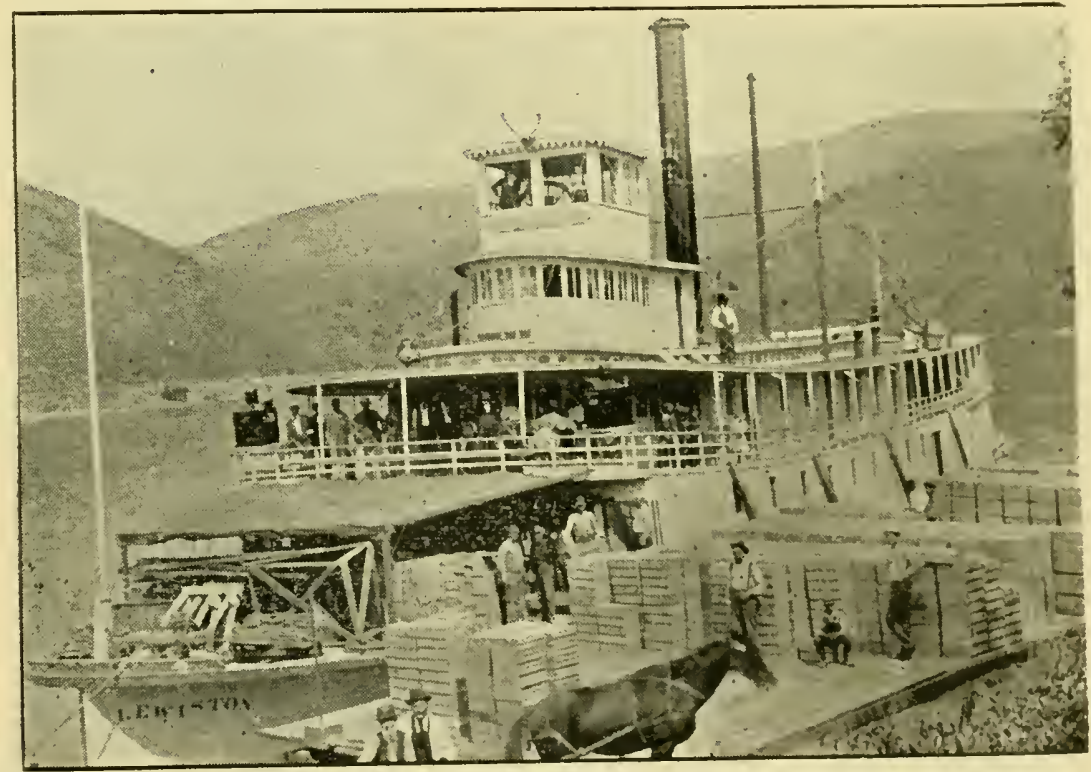

I,oading Fruit on Snake River Steamer, 17 miles from Pullman.

In sone of the low valleys of Eastern Washington, the tenuperature in smmmer sometimes rises somewliat liglier, but there lias never been a case of sunstroke in the Palouse country. The extrene dryness of the air in warm weather undoubtedly accounts for this fact.

\section{Farming, and its Results.}

The earl:est settlers cane into this comntry abont 30 years ago. (of the crops first grown, wheat prover the n110st renumerative, and the yield being so large, wheat raising becanne almost the exclusire feature 
of farming. Authentic records exist of yields of over 60 bushels per Crop Yields acre, without fertilizers of any kind. The average yield Crop Yields. is not this large by any means, but this shows what the soil is capable of in a gool season. We have farmers here who get 40 bushels per acre right along. Nosoil in the world laughs louder when it is tickled than the Palouse country soil. The 4o-bushel farmer is the man who studies his busines., reads good agricultural literature, gets the free bulletins from the State Experiment Station, visits the Station farm when he is in Pullman, attends the farmers' institutes,

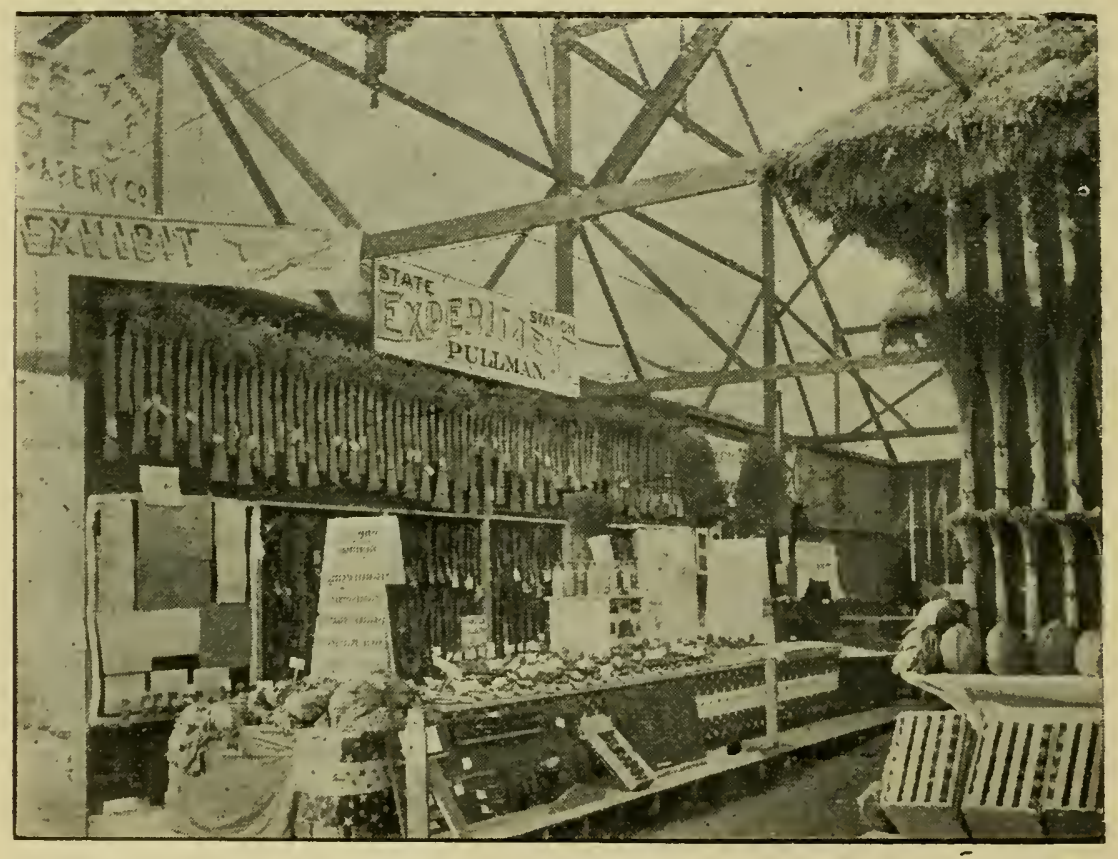

Fixhibit from Fxperiment Station Farm, Pullman, at Spokane Fixposition. keeps livestock, and is not afraid to think and work too.

Wheat raising has been so nearly niniversal that most farmers do not yet know what other crops can be grown here. The State Experiment Station has geen growing everything it could hear of during the All Crops do past eight years, and many progressive farmers have Well. grown other things than wheat, so that we know that
many other crops do just as well as wheat. In fact, we can grow anything that grows in Wisconsin and Southern Minnesota. 


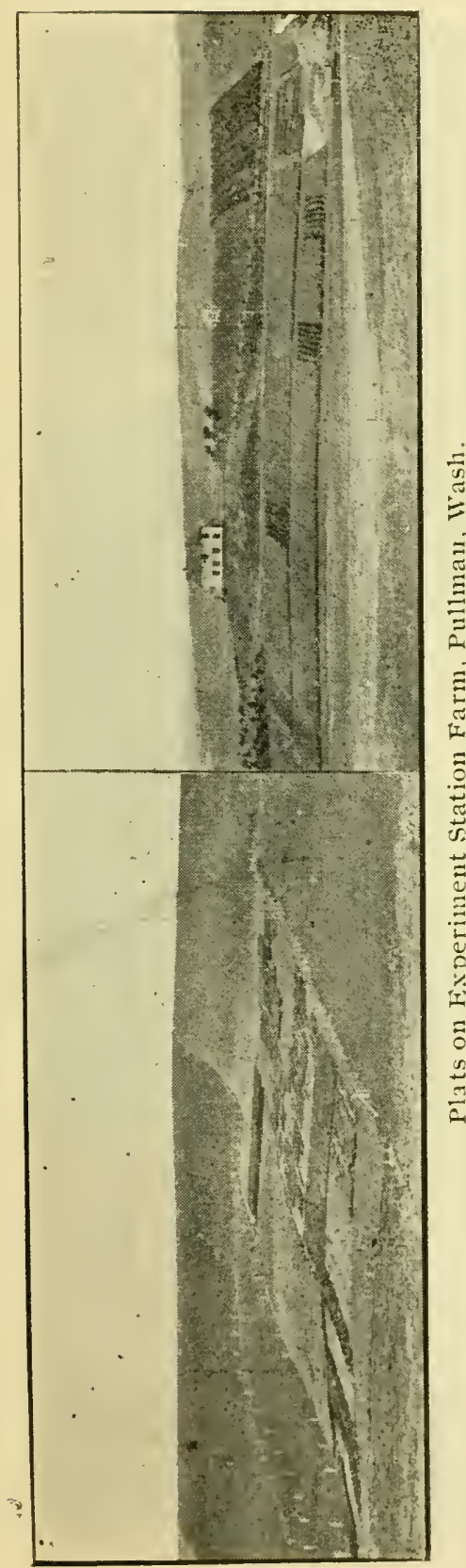

Fruits and Crops that do just as
Vegetables, Oats, barley, spelt, rye, flax, sugar beets, rape, rutabagas, mangel wurzels, potaţoes and pease. We cliallenge the world to grow better winter apples, and any small fruits, than we grow in the vicinity of Pullunan.

\section{Grasses and Forage Plants.}

On low lands, and on all lands except the dryest south lillsides, timotliy and clover grow abundant$1 y$ in the vicinity of Pullman, and yield 2 to $3 \frac{1}{2}$ tous of liay per acre according to location and treatment of the soil. Ondrier lands, orchard grass is a fine hay grass, and also an excellent pasture grass. For permanent pasture, brome grass (Bromus inermis) is a magnificent success all over $₫ ! ?$ wheat section, and it yields large crops of hay or seed the second and third seasons. Kentucky blue grass grows 3 feet higl on 1110ist low lands, and white clover thrives witl it. Mearlow fescue, Italian rye grass, and tall meadow oat grass, are all perfectly at liome here. In fact there is 110 trouble to raise plenty of tame grasses.

One of the first questions an Eastern farmer asks about this country is, "Can you grow corn?" On the upland prairies of Eastern Waslington, where the altiturle is over 2000 feet, it hardly pays to grow 


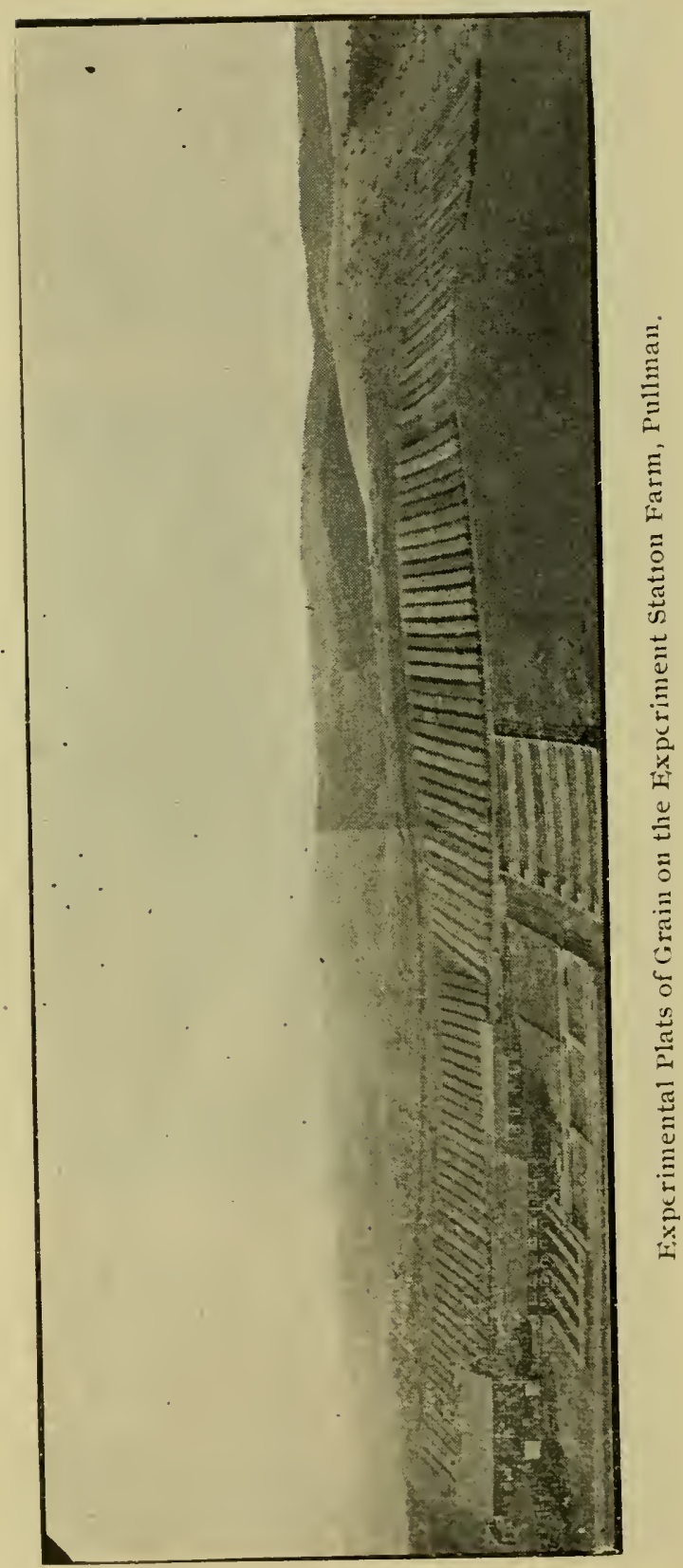


corn for grain on land that will grow 60 bushels of barley to the acre.

Corn for

But more cow feed can be grown per acre with corn

Fodder. right here than with any other crop. We have grown corn every year since i 893 , and have never failed to get our silo full of first-class ensilage. The smallest yield we ever had was Io tons of silage per acre.

\section{Livestock in the Palouse Country.}

There is no question that we have here a magnificent livestock and dairy country, mexcelled anywhere. Mr. Wing said of it: "In all

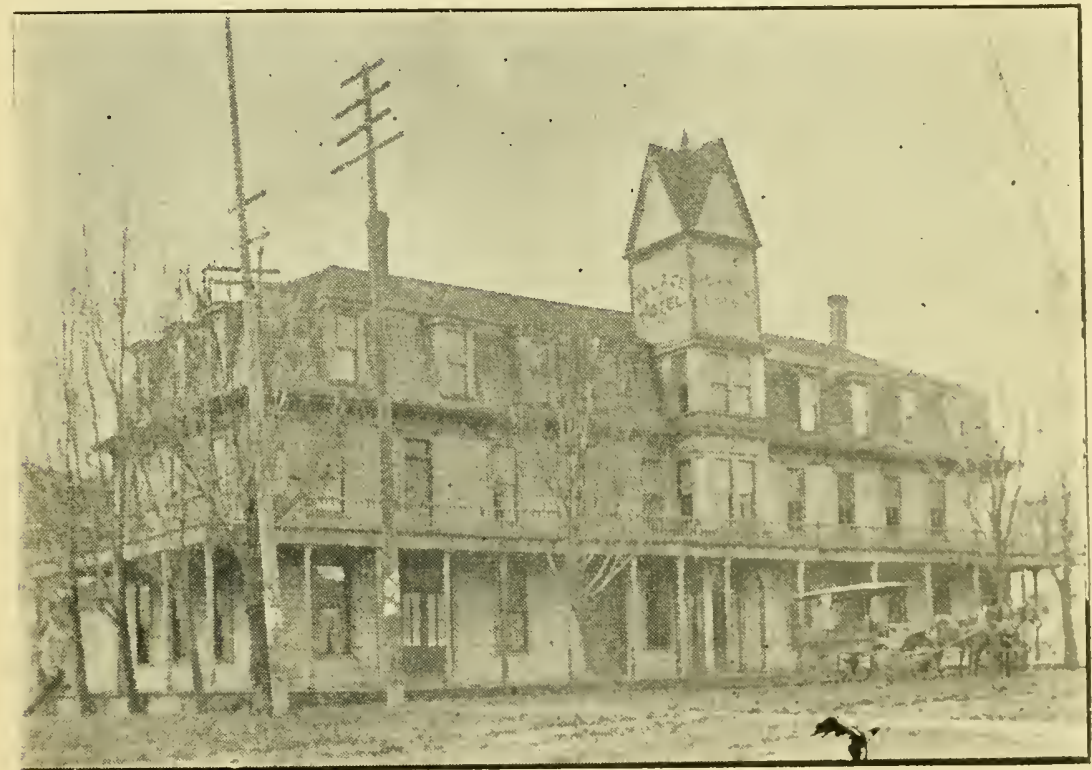

Palace IIotel, Pullman, Wash., Theo. T. Davis, p'roprietor.

the long journeys I have made, I have never seen anything that seemed to me to have the natural alvantages for humbulife and occupation than this Palouse country las. The only uncultivated land is along the lower slopes where the rocks may outcrop. The soil is dark browl1. It is rich. It is immensely rich. It seems larally affected by the twenty years of cropping, as yet, and the crop is wheat. It seems to me that here is the best place to build a stock farm that I have seen on this trip." [Mr. Wing, when he Was at Pulluman, hat 
just passed through California and Oregon.]

Dr. E. N. Hutchinson, inspector in charge of the work of the Bureau of Animal Industry at Portland, Oregon, says that the section between the Cascades and the Rockies produces the healthiest mutton in the world, the sheep being freer from parasitic diseases than anywhere else in the country; and he ought to know, for he inspects the carcass of every animal slaughtered at Portland.

\section{The System or Farming for the Palouse Country.}

The system of crops best adapted for a livestock farm in the ricinity of Pullman would be about as follows, 160 acres being taken as a basis: Reserve ten acres for yard, barnyard, garden, orchard and runs for calves, pigs and chickens. Seed down to permanent pasture the lowest portions of the farm, say 25 acres, using timothy, red top, blue grass, meadow fescue, Italian rye grass, red clover and white clover as a mixture. Divide the remaining 125 acres into five fields as nearly equal in area as the configuration of the land will justify. On these five fields grow a rotation of wheat, timothy and clover, timothy and clover (2nd year), oats and pease (for hay), corn and potatoes. About one-third of the manure should be plowed in in early spring on the field that is that year to be sown to timothy and clover, the remaining two-thirds to be put on the 2nd year timothy and clover sod and plowed under in the fall before sowing pease and oats in the spring. With this system any one field will be in wheat one year in five, followed by two years in grass, one in pease and oats, and one in cultivated crops. The rotation may be varied by replacing part or all the wheat with barley, flax, rye, oats, or spelt. Any of these last named may also replace the oats and pease, and be used either for grain or hay as convenience may require. Corn and potatoes may, as occasion requires, be replaced by sugar beets, or root crops for slicep and cattle.

The yields from such a system of cropping that a farmer may fairly expect, with good management, are about as follows: Wheat, 35 to 45 bushels per acre; first year grass fields, abundant fall pasture; 2nd year grass field, 2 to $3 \frac{1}{2}$ tous of hay per acre, with abundant pasture after haying; pease and oats, 2 to 4 tons of hay per acre ior barley 60 bushels, or oats 60 bushels); corn (for silage) Io to 15 tons per acre; potatoes 150 to 300 bushels per acre: carrots or mangels, 20 tons; sugar 
beets, Io to 12 tons per acre.

Such a farm would raise feed for 26 milk cows, with the necessary complement of horses, young cattle, hogs, sheep, and chickens. Two

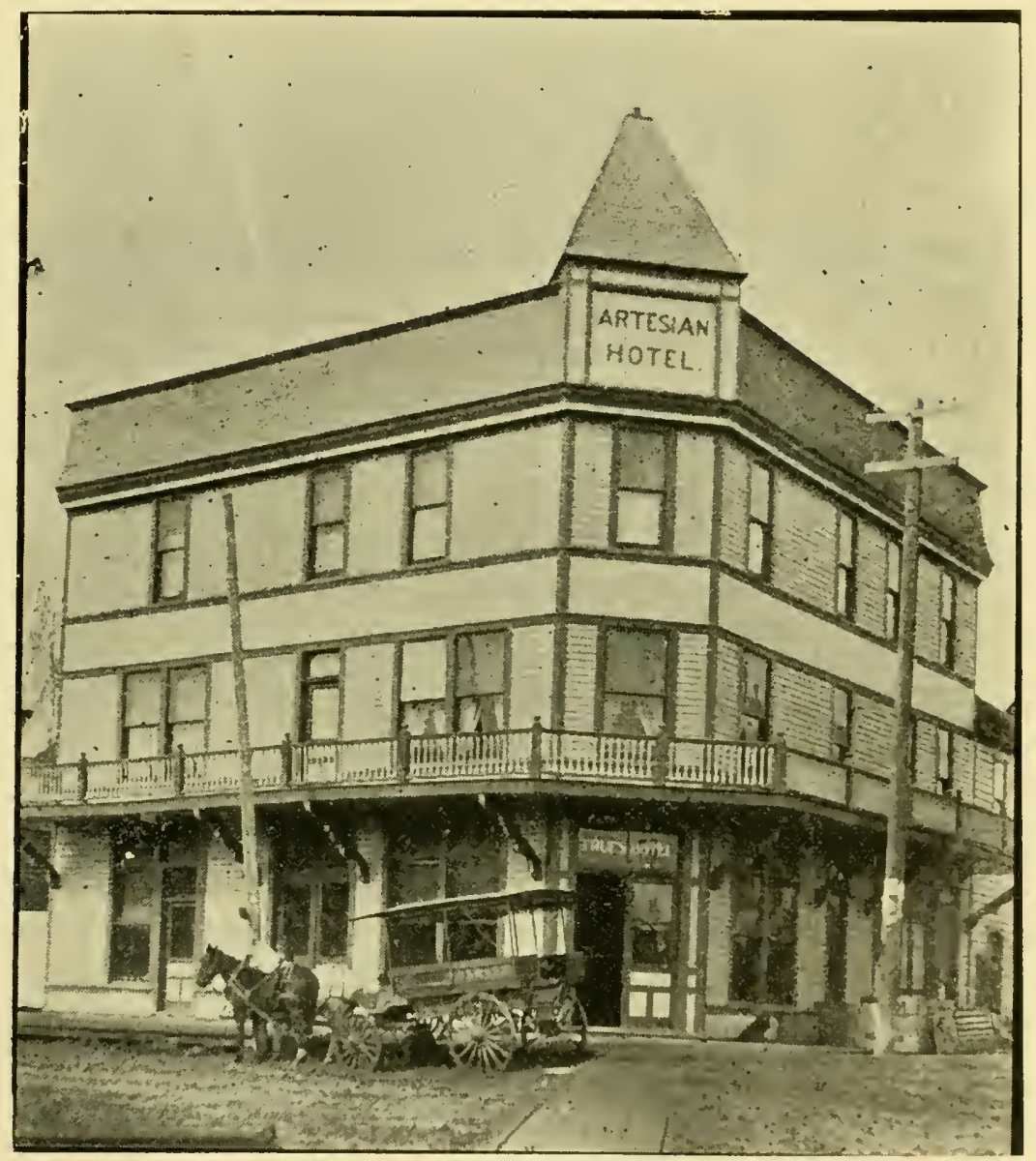

Artesian Hotel, I'ullman, Wash,, M. C. True, Propr.

men could do practically all the work on such a farm except the threshing.

The above yields are not fanciful, but are taken from the actual experiences of a farm run on this system at Pullman.

('The above article was written for this pauphlet by Prof. W. J. Spilluan, professor of agriculture, of the State Agricultural College and School of Science, I'ulluan.) 


\section{Facts About the Palouse Country.}

Tornadoes, cyclones and heavy thunder storms are unknown.

Fleas and mosquitoes have not yet found the Palouse country.

Small fruits? They are in their natural element in the Palouse country.

It is difficult to find a quarter section that does not have on it one or more fine springs.

No irrigation required. All grains, fruits and vegetables grow to perfection without it.

Palouse fruit is noted for its fine flavor, being much better in this respect than fruit from Oregon or California.

Both winter and spring wheat are grown, and harvest commences about July I $5^{\text {th }}$, continuing till October ist.

The sugar beet grown in Palouse soil has no superior, and finds ready market at a good price at the Waverly factory.

Such apples grow no where else in the world. They are free from worms, and flavor and keeping qualities are the best.

Wood is generally used for fuel, the timbered mountains a few miles to the east furnishing an abundant and cheap supply.

Palouse farms are all well watered, there being numerous living springs, and artesian water being found at a depth of from 80 to 120 feet.

The record crop of wheat, Ior bushels from a single acre, was grown by E. J. Northcutt near Pullman. You saw this wheat at the world's fair. 
The Palouse soil requires no fertilizer, wheat averaging 25 to 50 bushels, oats 40 to 100 bushels, and barley 30 to 60 bushels per acre without it.

The Palouse valley is a prairie country, but there is an abundance of timber to the east, the timber line being twelve miles from Pullman. The price of four-foot wood in the timber is \$I.50 per cord.

'The various grasses and leguminous plants flourish, and dairying is making rapid strides, promising to become one of the leading industries of this section. In our short open winters stock requires but little feeding.

From a patch of ground 50xi20 feet, within the city of Pullman, S. Shearer during the past season sold $656 \mathrm{full}$ quarts of luscious berries, realizing therefrom $\$ 65.65$. This was in addition to the berries used by the family, and I6 gallons of preserves made.

It would appear from what we already have, that Nature has given us more than our share, but from present indications another great source of revenue is to be opened up. According to expert report large bodies of gas and oil underlie the Palouse country. Machines are being brought in to prospect this section, and the coming season will find many wells driven.

The poultry industry offers great inducements. Iiggs find read sale the year round, the prices ranging from I 5 cts. in summer to $40 \mathrm{cts}$. in winter, the average being about $25 \mathrm{cts}$. per dozen. At the last show of the Whitman county poultry association, held in Pullman during the last winter, upwards of rooo birds were exhibited, the number including some blue-blooded and high scoring fowls.

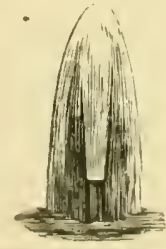




\section{P U L L M A N}

In the heart of this fertile region is located the city of Pullman, the railroad, commercial, educational and social center of the great Palouse country.

Owing to the conformation of the country "all roads lead to Pullman," and there is marketed here every year upwards

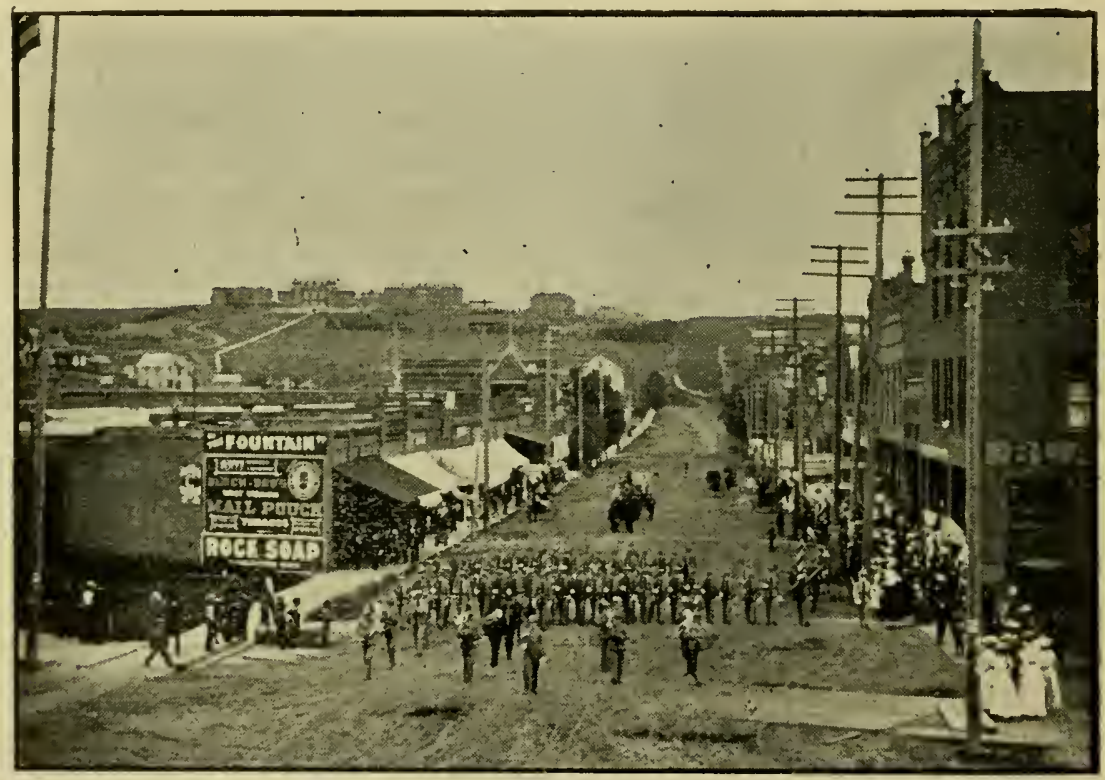

I,ooking Fiast on Main street, Pullnan, Wash.

of half a million bushels of grain, as well as immense quantities of fruits, vegetables, and other prcducts. It has railroads, the Northern Pacific and the O. R. \& N., leading in five directions, giving it unexcelled shipping facilities, and creating lively competition in the grain market, often raising the price of grain considerably over that of the surrounding 
towns which are less favored with transportation lines.

The Northern Pacific has also purchased right of way for a "cut-off," running from Pullman to connect with the main line at Connell Junction, which will serve to greatly shorten the distance by rail to the Coast points, and which will cause the grain of the entire Palouse and Potlatch countries to find tide water market via. Pullman.

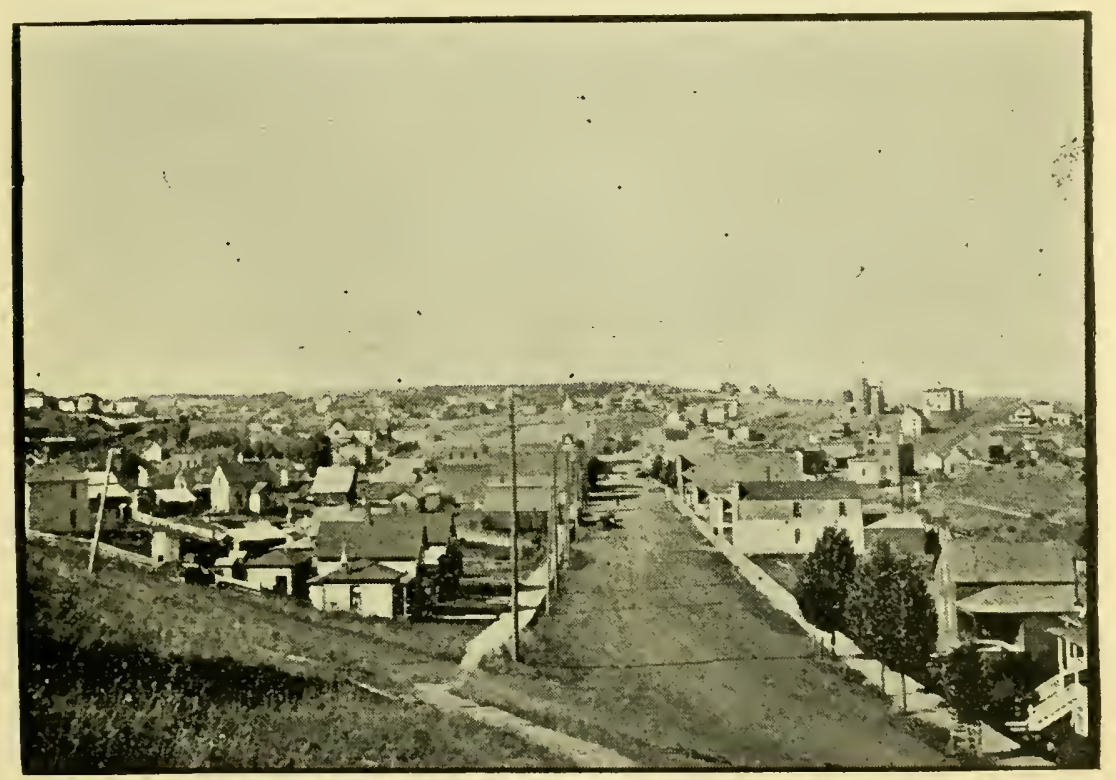

I,ooking West on Main street, I'ıllman, Wash.

Pullman is a substantially built city, with handsome business blocks of brick, with graded and in many cases macadamized streets, and well-kept sidewalks. Stocks of general merchandise are carried by Pullman merchants that would do credit to a city of 25, coo inhabitants, this being made possible by the large tributary country from which trade is drawn. 
The public schools of the city are a source of great pride, being under the able superintendency of Prof. C. W. Bean, former state superintendent of public instruction, with a most capable corps of teachers. The school building is a handsome structure that cost over $\$ 30$, 000 .

Pullman has an excellent water system, under municipal management, and is lighted with electricity.

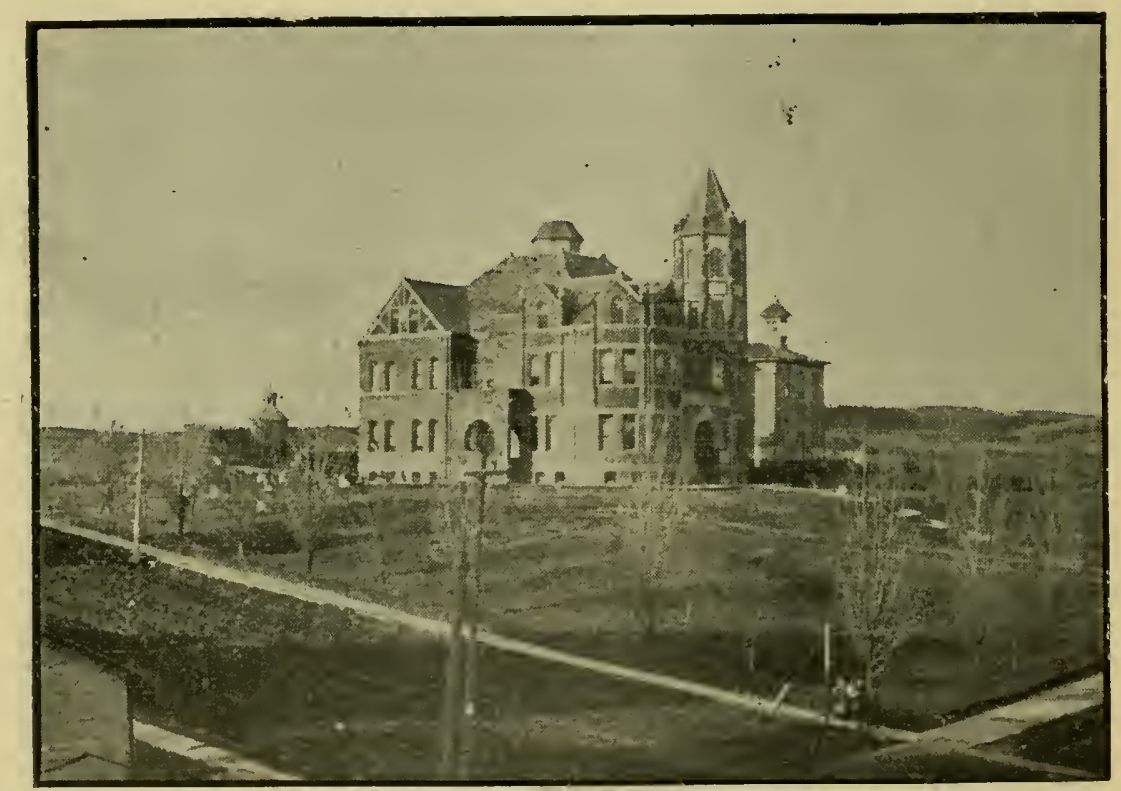

Pullman Public Schcol Building.

In climate and soil, and conformation of country, Nature was kind to Pullman, but one of her richest gifts, and one responsible in a great measure for the proverbial healthfulness of the place, was artesian water. From 80 to 120 feet below the surface is a basin of the purest of cold artesian water, that gushes forth wherever tapped, and fourteen wells are already flowing within the city, some of which have been flowing for ten years, and show nudecrease in volume. 'The 
water is strongly mineralized, and has pronounced healthgiving properties.

In home and social life Pullman is a place of consider able attractions. The social atmosphere is extremely pleasant, the people being genial-hearted and friendly. It is a town of comfortable and attractive homes; hospitality is one of its virtues, and social gatherings are among its leading enjoy-

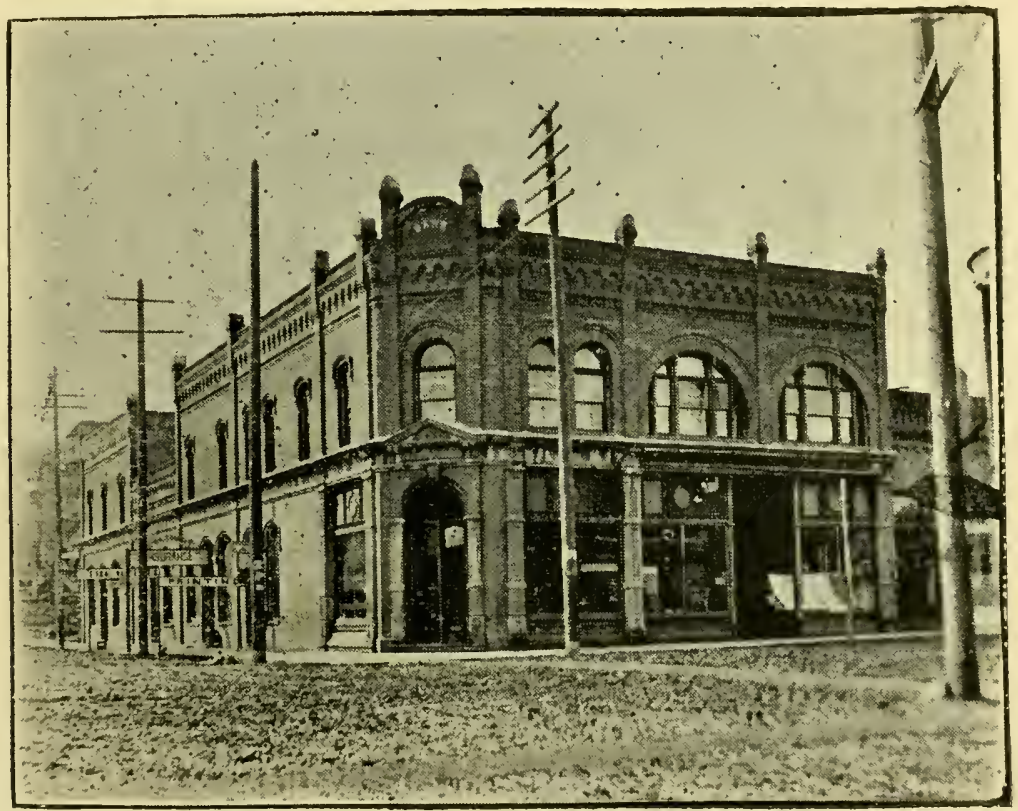

Furst National Bank Building, P،1lman, Wash.

ments. It is the universal verdict of its visitors that there are few communities where the people respond more readily to the social instincts, or where newcomers can so soon find congenial friendships. When one considers how large a place in the comfort and happiness of life the matters of neighborly cordiality and social enjoyment hold, it will be realized that residence in a town where these claims are 
bonored as they are in Pullman becomes a very pleasant thing. Warm-heartedness is a characteristic of its people, who are always ready to extend a welcome to strangers, and a share in the pleasures of its social life to the newcomers among its population.

As is usual almost everywhere, the churches form, to a considerable degree, the centres of the social life of the peo-

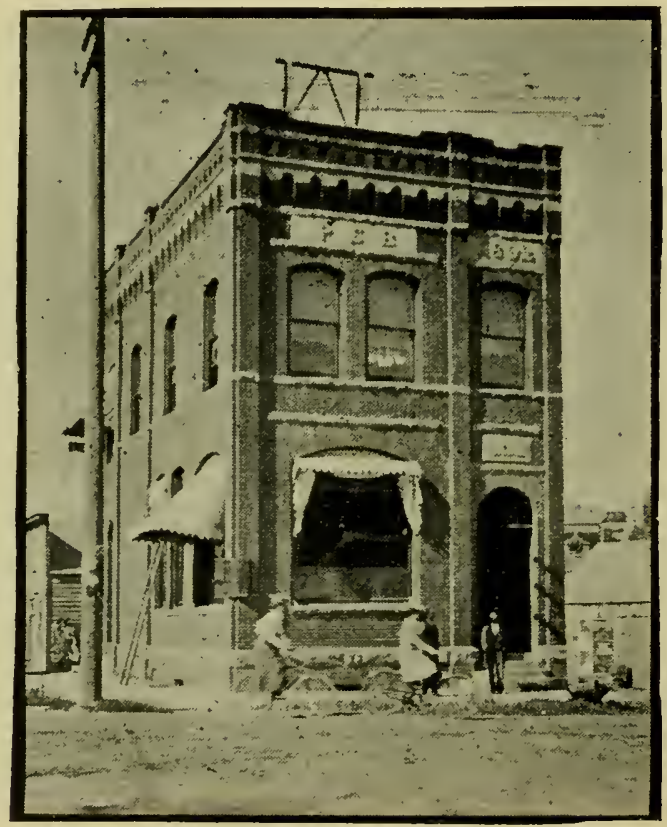

State Bank Building, Pullman, Wash.

ple. Religious institutions exist not merely to enlarge the society of Heaven, but also to add to the advantages and enjoyments of the social life on earth. Pullman has six churches. They are the Baptist, Christian, Congregational, Protestant Episcopal, Methodist Episcopal, and United Presbyterian. There are also occasional services at stated perjods under the auspices of the Roman Catholics and Luth- 
erans. The city, it will be seen, is well supplied with churches, and they are hard-working and helpful institutions. The Sunday schools are well-organized and zealous in their care of the children. There are flourishing societies for the young people. In fact every religious institution which one is accustomed to meet with elsewhere is to be found here,

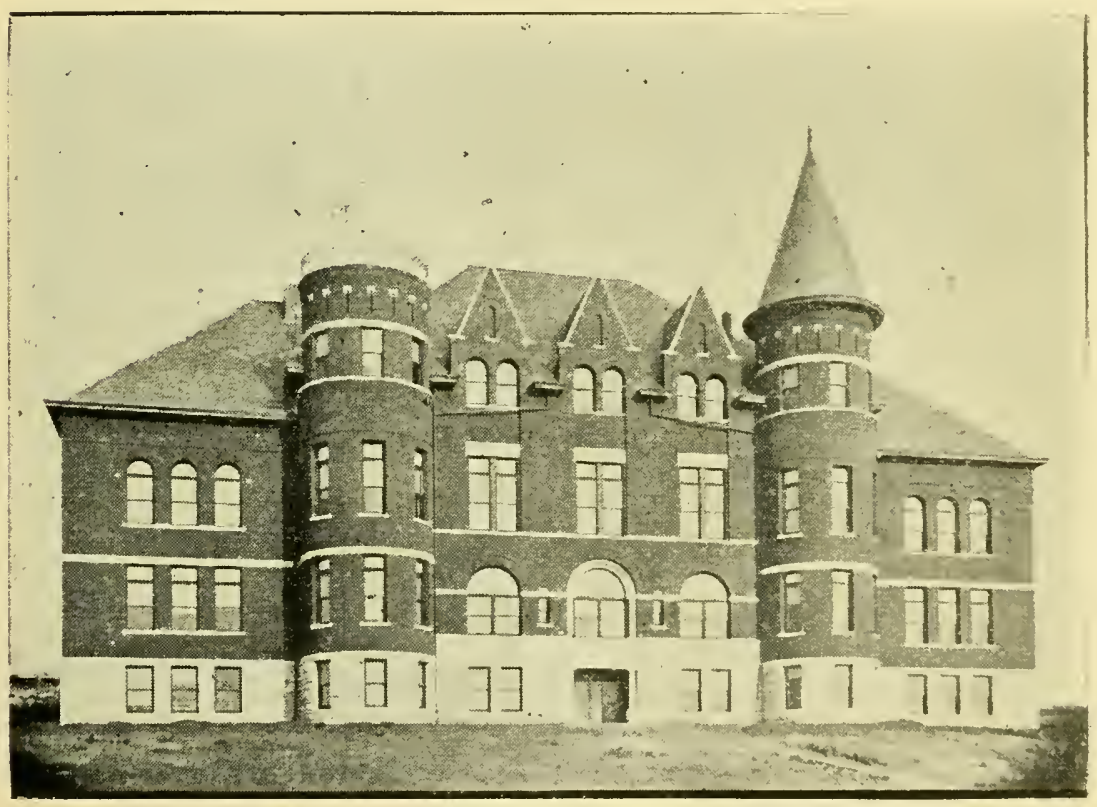

Administration Building, State Agricultural College and School of Science.

working in the cause of social and moral betterment. Pullman is a pleasant place in which to live; and it is also a safe place. With its social and educational and religious advantages, it would be difficult to find a more attractive place for settlement in the West than is offered here.

Pullman is the seat of the State Agricultural College, Experiment Station and School of Science. 'T'his is one of the 
largest colleges in the Pacific Northwest. Though but eight years old, it has a faculty of thirty-five, and a membership of five hundred students. It has eight principal buildings, besides its farm buildings. It is under the management of Enoch A. Bryan as president. It offers the following collegiate departments of study and the following schools:

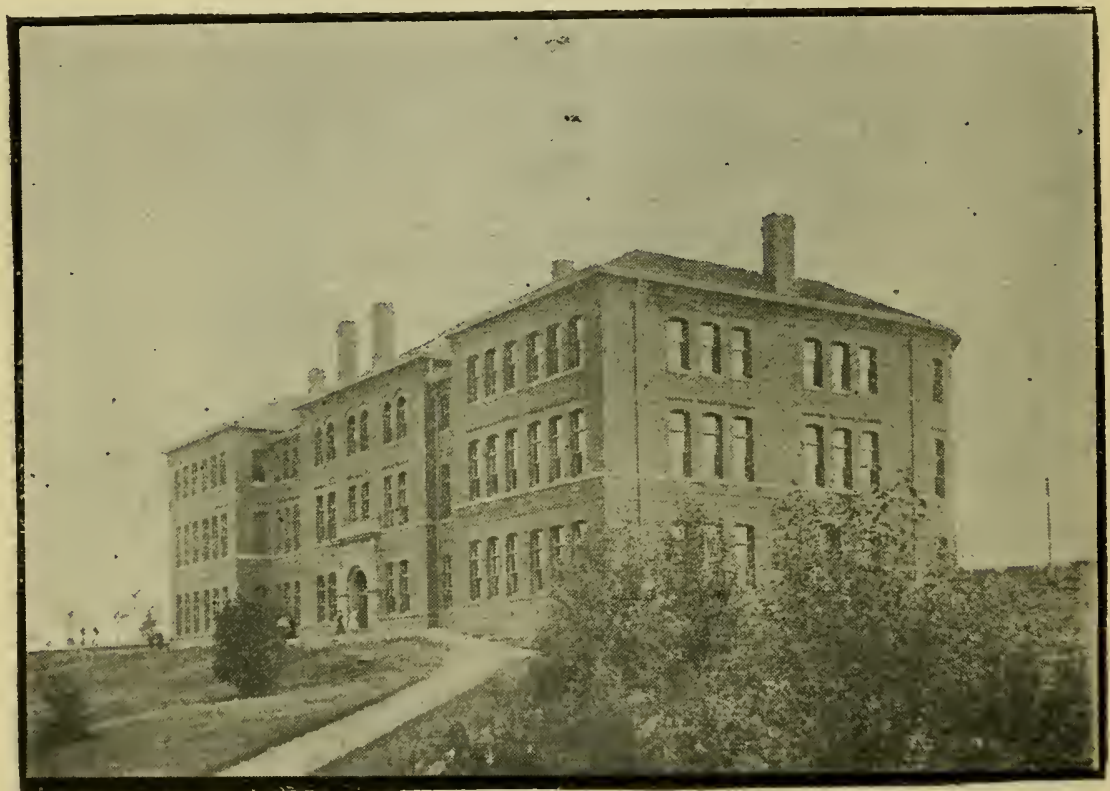

Science Hall, State Agricultural College and School of Science.

Department of Mathematics and Civil EngineerING, including - (a) Mathematics; (b) Civil Engineering.

- DEPARTMENT OF CHEMISTRY.

DEPARTMFNT OF BOTANY AND ZOOLOGY.

DEPARTMFNT OF AGRICULTURE.

DEPAR TMENT OF HORTICUlTURE.

DEPARTMFNT OF ENGLish LANGUAGE AND Literature. 
Departant of Economic Schince and History.

Departinent of Mechanical, Exginefring, including -(a) Electrical Engineering; (b) Steam Eangineering; (c) Water Power Development.

DEPARTMENT OF MODERN IANGUAGES, including-(a) German; (b) French; (c) Spanish.

Departaent of Mining ENGINEFring.

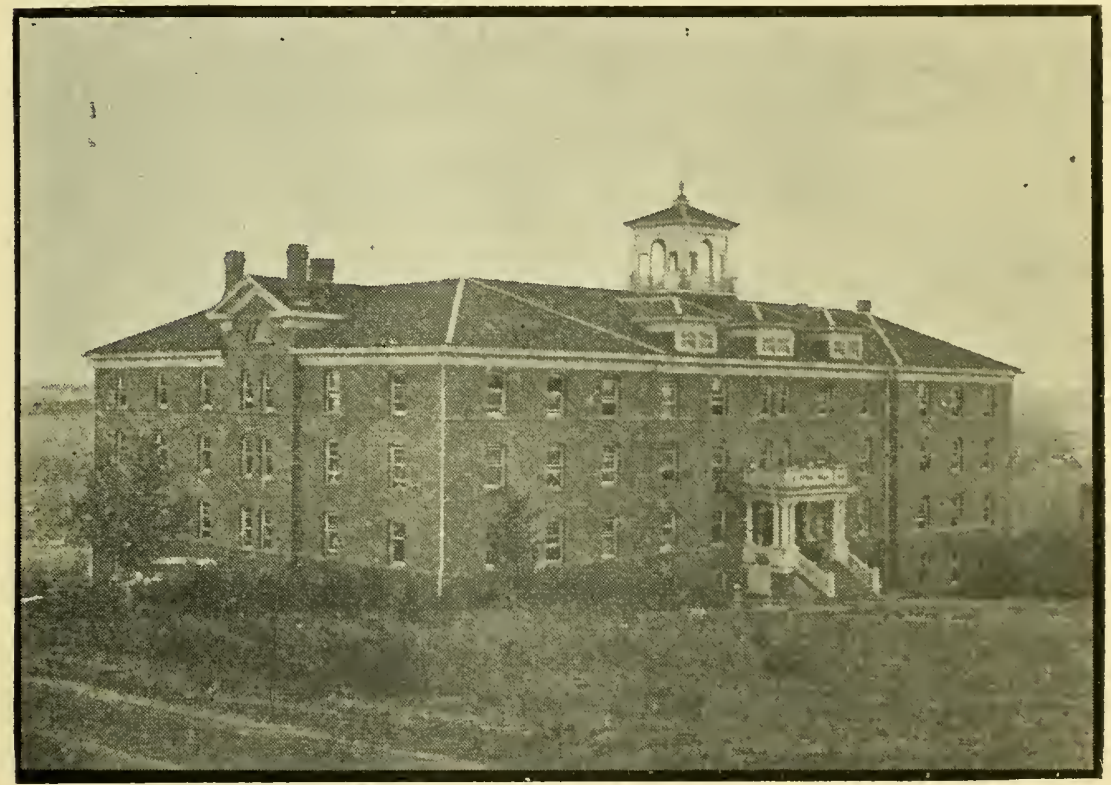

Ferry Hall, State Agricultural College and School of science.

Départment of Military Science and 'TACTics.

Courses of instruction supplemental to the work of the foregoing departments are offered as follows:

Course in Physics.

Course in Geology and Mineralogy.

Course in IATTiN.

COURSE IN EinUCATION. 
School of Agriculture (three years):

SCHOOL OF DAIRYING.

SCHOOL, OF PHARMACY.

SchoOl OF Veterinary ScIEnce.

SCHOOL, OF BUSINESS.

SCHOOL FOR ARTISANS.

Short Course in Assaying and Mining (twelve weeks).

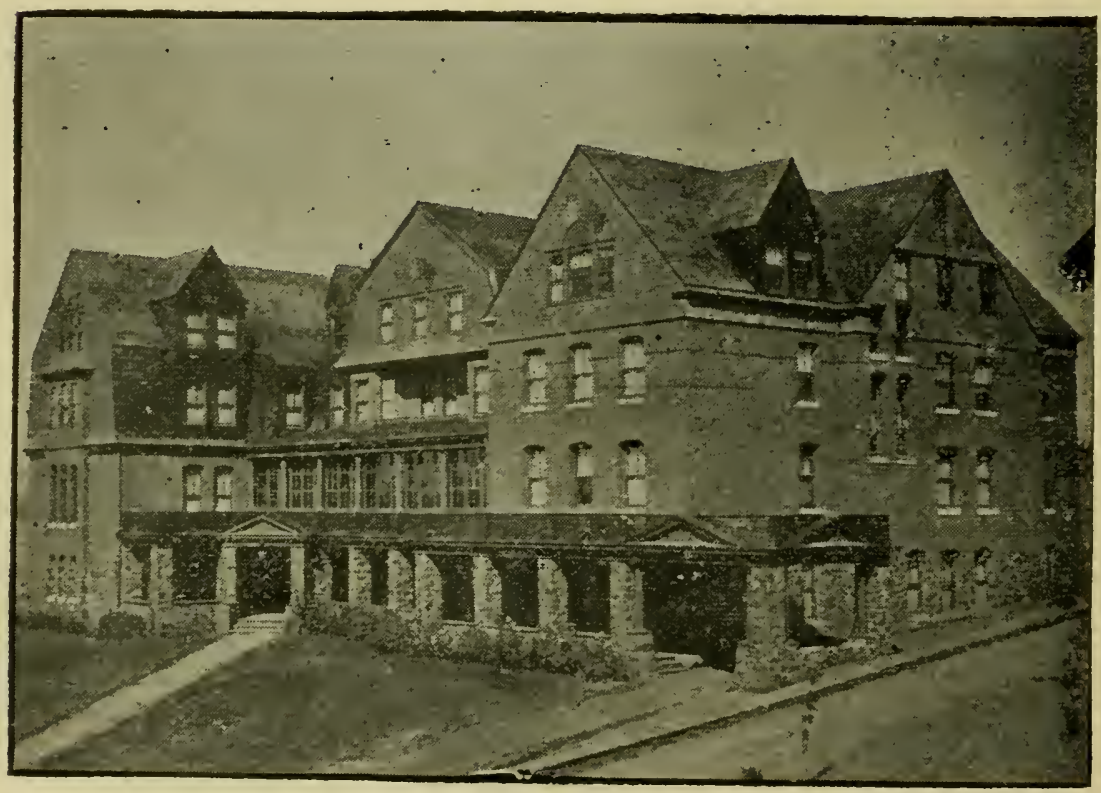

Stevens Hall, State Agricultural College and School of Science.

PREPARATORY SCHOOL (three years).

There are 250 acres of land in the college farm and campus. 'The college receives $\$ 25,000$ a year from the United States, and the Experiment Station \$I 5,000 a year. It also receives appropriations from the state. Its buildings and apparatus are worth more than a quarter of a million of dollars. 


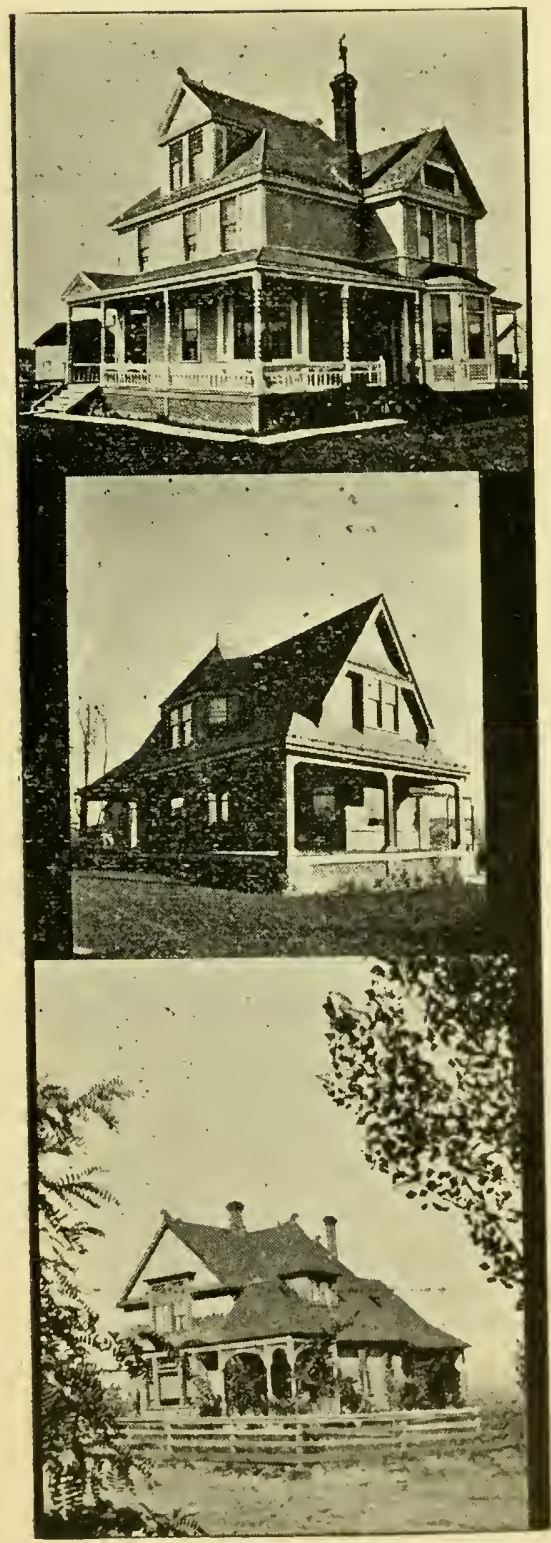

Group of Pulluan residences.

\section{A few Prices.}

The following are prices of a few staples in Pullman:

Country Butter, per 1b........20 cts. Creamery Butter per 1b.......35 cts. Cream Clieese per $1 \mathrm{~b} . .$. IS to $20 \mathrm{cts}$. Flour, best patent, 50-11) sk...75 cts. Dried Peaches, per lb...6 to ro cts. Dried Apples per 1b.......5 to 8 cts. Dried Prunes per $1 \mathrm{~b} . . . . . . . . . .6 \mathrm{cts}$. Hams and Breakfast Bacon per $1 b$. ........................ I 2 to $\mathrm{I}_{5} \mathrm{cts}$. Shoulders per $1 \mathrm{~b} . . . . . . . . . . . . .$. ro cts. Lard per $1 \mathrm{~b} . . . . . . . . . . . . . . . .$. I I cts. Sugar, gramulated, per $1 \mathrm{~b} \ldots . . .7 \mathrm{cts}$. Sugar, Ex. C., per $1 \mathrm{~b} . . . . . . .61 / 2 \mathrm{cts}$. Potatoes per sack..............6o cts. Eggs per dozen............ I 5 to 40 cts. Canned corn, tomatoes, etc., per can........................... ro cts. A rbuckles Coffee per $1 \mathrm{~b} . . . . . . .15 \mathrm{cts}$. Gree 11 and black Teas per $1 \mathrm{~b} . . . . .$. . ...........................40 to $75 \mathrm{cts}$. Barbed Wire per cwt..........\$4. $\$ 5$. Prints per yard.............4 to $5 \mathrm{cts}$. Amoskeag Ginghams per yd.6 cts. Unbleached Muslin peryd. 5 to 8 cts. Bleached Muslin per yd...6 to rocts. Lumber, rough boxing, per M...\$I I. Lumber, finishing, per M.,......... Shingles per M................. $\$ 2.00$.

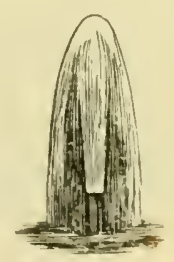




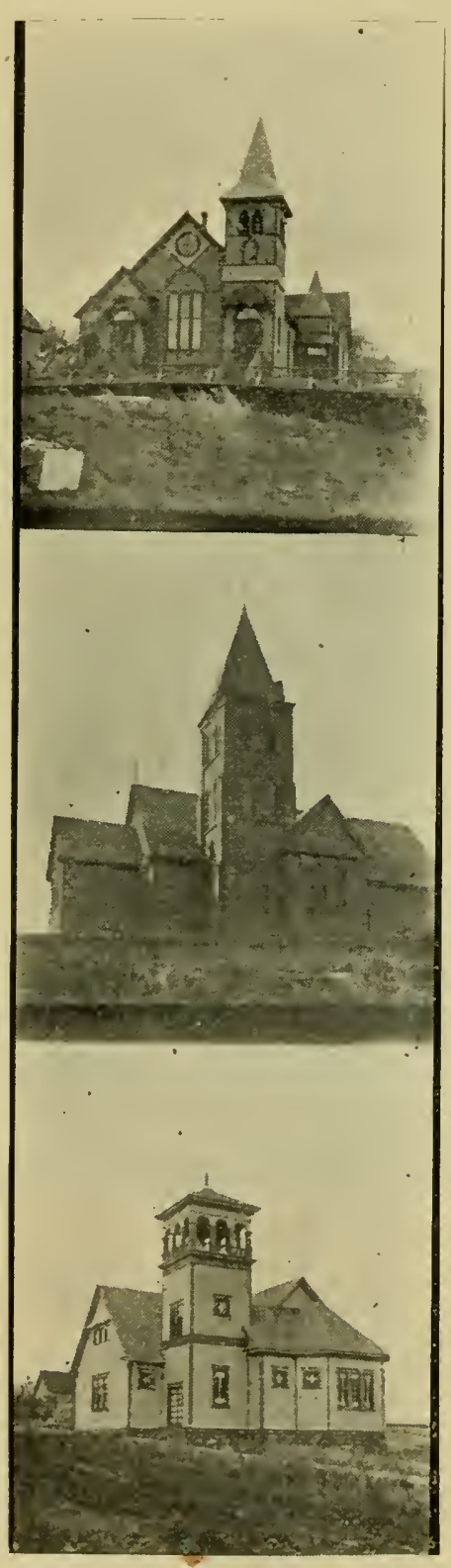

Congregational Church. Yipiscopal Church.

United Presbyterian Church.

\section{Pullman Has}

2 Banks.

3 Hotels.

4 Doctors.

2 Dentists.

2 Bakeries.

5 Lawyers.

6 Churches.

2 Tin shops.

I Feed store.

2 Drug stores.

3 Cigar stores.

Electric lights.

2 Barber shops.

I Lumber yard.

I Flouring mill.

I Harness shop.

2 Meat markets.

2 Grocery stores.

2 Jewelry stores.

3 Livery Stables.

I Machine Shop.

I Bottling works.

I Furniture store.

I 4 Artesian wells.

I Hardware store.

2 Millinery stores.

I Steam Laundry.

4 Blacksmith shops.

I Second-hand store.

I Confectionery store.

I Photograph gallery. 


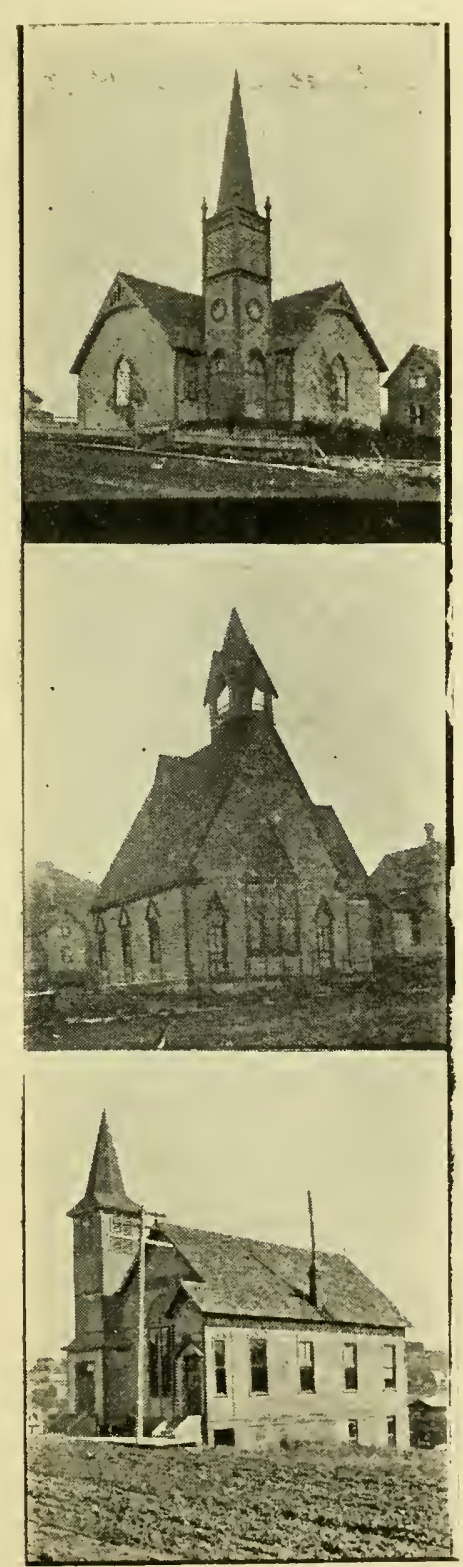

Methodist Churcl. Baptist Church. Christian Churcls.
Good sidewalks.

2 Implement houses.

Railroads in five directions.

I News and stationery store.

4 General merchandise stores.

Graded, macadamized streets. tem.

Magnificent public school sys-

State Agricultural College, and School of Science.

The best opera house in Eastern Washington.

Seven mammoth grain warehouses and elevators.

2 Newspapers, - The Herald, the pioneer paper, established I888, and The Tribune, established I 89 I.

\section{Pullman Needs}

Saw mill.

Box factory.

Planing mill.

Iron foundry.

Starch factory.

Beet sugar factory.

Cold storage plant.

Commission house.

Liuseed oil factory.

Straw board factory.

Nursery and green house.

Fruit and regetable cannery and evaporator. 


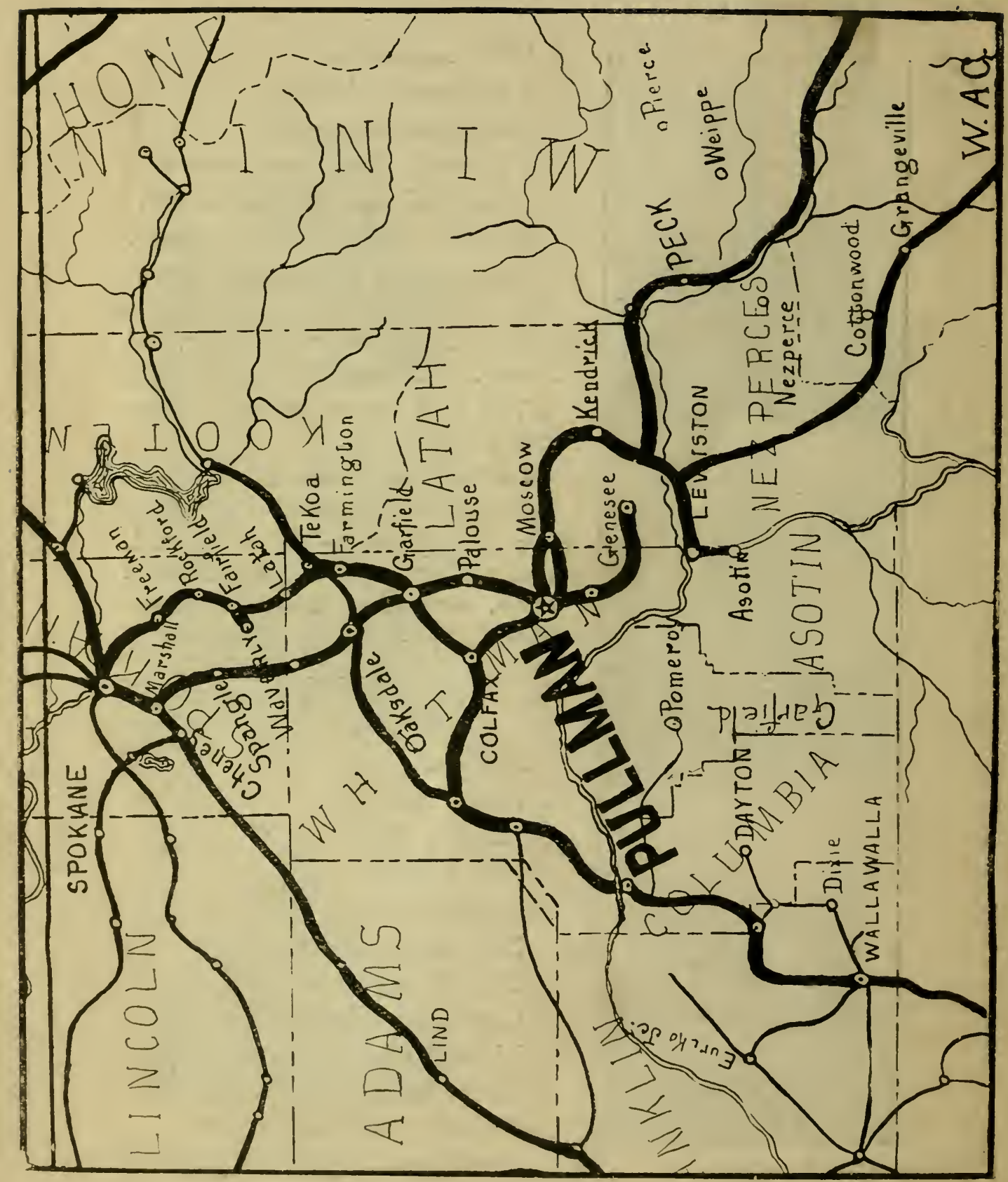

